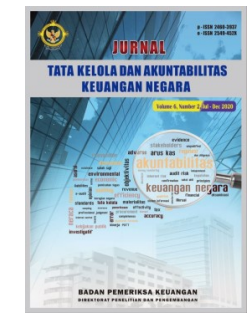

\title{
ANALYSIS OF BPK LEGAL BASIS FOR FORESIGHT AUDITORS FOR THE ACCELERATED ACHIEVEMENT OF THE SUSTAINABLE DEVELOPMENT GOALS
}

\author{
Angga Kiryaditama Putra \\ Badan Pemeriksa Keuangan Republik Indonesia, Indonesia \\ angga.putra@bpk.go.id
}

\begin{abstract}
Law Number 15 of 2004 and Law Number 15 of 2006 only lay down the authority of the BPK in conducting audits in general and the types of audits that can be conducted by BPK. These regulations, however, do not specifically and explicitly provide the authority to the conduct of a foresight audit. Foresight audit launched by BPK in the 2016-2020 BPK Strategic Plan will be very important in the achievement of sustainable development goals (SDGs) by 2030, given that the BPK will provide feedback and suggestions on important future policies to accelerate the achievement of SDGs. Legal instruments have an important role for BPK as the legal basis for the institution in achieving the Highest Maturity Model of the Accountability Organization in conducting a foresight audit. This study employs a normative legal research method that aims to explore and study regulations that support BPK as a foresight auditor in the future. The results illustrate that the legal basis or legal instruments for the exercise of BPK's foresight audit authority is sufficient but still needs to be improved. The addition of legal instruments and authorities can be a solution to ensure that any foresight audit performed in the future can run optimally and accelerate the achievement of the SDGs.
\end{abstract}

\section{KEYWORDS:}

Authority; foresight audit; legal basis; SDGs; policies

DOI: $10.28986 /$ jtaken.v6i2.383 


\section{INTRODUCTION}

The Supreme Audit Board of the Republic of Indonesia (BPK) is one of the state institutions that are identified in the most fundamental basis of all legal instruments in Indonesia, namely Indonesia's amended Constitution of 1945. Not many external audit institutions in other countries enjoy the high position afforded to BPK in Indonesia. In this regard as a state institution, BPK has the constitutional authority to examine the management of and accountability in state finances which is expressly provided in Article $23 \mathrm{E}$ of the amended Constitution. Article $23 \mathrm{E}$ is elaborated into a regime of laws regarding state finances consisting of Law Number 17 of 2003 concerning State Finances, Law Number 1 of 2004 concerning State Treasury, and Law Number 15 of 2004 concerning The State Financial Management and Accountability Audit. As such, the general authority of BPK as an external auditor of state finances mandated in Article $23 \mathrm{E}$ of the amended Constitution and the regulatory instruments governing state finances are sufficient. However, according to the author's hypothesis, there is still an absence of rules that specifically grant authority relating to foresight audits.

The roles, functions, and duties of BPK as a foresight auditor will be greater as BPK would be tasked with rendering its considerations and views on future policies to stakeholders, especially the government. In other words, BPK must have a visionary view going forward to determine future government policies with support from adequate regulations. In determining future government policies, BPK can consider achieving 17 sustainable development goals by 2030 through recommendations given. In achieving the Sustainable Development Goals (SDGs), a compilation of 17 global goals with 169 goals, the Supreme Audit Institutions (SAIs) are invaluable. In promoting and fostering the effi- ciency, accountability, effectiveness, and transparency of public administration, the United Nations (UN) believes SAIs are important. The International Organization of Supreme Audit Institutions (INTOSAI) has set out to develop a framework for SDGrelated audits. Because SDGs are global agendas, now, more than ever, coordination between SAIs in an audit is imperative (Rajaguguk, Yatnaputra \& Paulus, 2017). In Europe, the European Court of Auditors has prioritized auditing the SDGs for several years. Half of 26 special reports and reviews were already concerned with sustainability issues in 2014. This was no accident, as sustainability auditing was one of our top three priorities in the strategy up to 2017 (Owen, 2019).

At present, BPK has basically paid attention to sustainable development as seen from the role of the Expert Staff on the Environment and Sustainable Development (Staf Ahli Bidang Lingkungan dan Pembangunan Berkelanjutan BPK). Also, the target of social welfare and environmental aspects has been contained in BPK's vision and mission. The compilation of SDG programs in the National Medium Term Development Plan (Rencana Pembangunan Jangka Menengah Nasional, RPJMN) also imposes an obligation to BPK to carry out audits related to the SDGs and will see the results/outcomes in the fifth year at the end of such RPJMN term (Simanjuntak, 2019). This is stated in Article 2 paragraph (2) of Presidential Regulation (Peraturan Presiden, Perpres) Number 59 of 2017 concerning the Implementation of the Achievement of SDGs which states that the national targets in the RPJMN are in line with the SDGs. However, BPK's recommendations for future government policy will continue to be one key to accelerate the achievement of the 17 sustainable development goals. BPK regulations and the legal basis on which it carries out its mandates are currently enough to allow it to perform au- 
dits at the foresight audit level, but improvement is still needed.

Types of audit, types of recommendation, forms of recommendation, scope limitations, scope, and support between agencies to carry out follow-up actions need to receive attention in these regulations for BPK to gain the support it needs as a foresight auditor. In a system of governance, a group of organs (tools) of the government both broadly and narrowly must work together to achieve the goals of the state, as is stated in the Preamble of the amended 1945 Constitution (Radjab, 2005). Given this requirement, the performance of a foresight audit would not be feasible if the auditee fails to work together with BPK to support the tasks and functions of BPK as the foresight auditor. BPK recommendations that are not followed through by the auditee may be one of the potential problems that BPK can face from lack of effective regulation and coordination. Auditee's views which often still look at BPK as an examining body and only look for mistakes or make audit findings must begin to be changed, including from internal BPK. The consequence of BPK acting as a foresight auditor is the creation of its role as an agent of change, functioning to fix the system, build ideas, thoughts, better ideas and provide recommendations on long-term policies or future policies to accelerate the achievement of the SDGs.

The program for developing planning objectives are summarized in the document "Transforming Our World: The 2030 Agenda for Sustainable Development". The program was prepared in the hope of answering the underdevelopment of countries around the world (Hoelman, Parhusip, Eko, Bahagijo \& Santono 2015). This program produces 17 points of sustainable development with 169 integrated and inseparable targets and is committed to achieving sustainable development in three main aspects, namely: eco- nomic, social, and the environment in a balanced and integrated manner (United Nations, 2015b). The role of the three main aspects is also mentioned in Article 2 paragraph (2) of Perpres Number 59 of 2017.

The accelerated achievement of the SDGs' goals is very dependent on how the government formulates its policies in the future. The determination of steps to be taken by the government in the long-term plan to achieve the SDGs goals is very important and crucial as it is a fact that the SDGs' goals cannot be achieved in an instant and within the short term. It takes time, energy, effort, and commitment from all parties to realize the goals. The dedication of several sovereign states and the unprecedented participation of civil society have made it clear that the 2030 Agenda and the SDGs are part of our society as a whole and call upon everyone's duty to adopt them: individuals, corporations, civil society organizations, and political and administrative forces at all levels (PesceMonteiro, 2019). With the mission of achieving the SDG goals and its aspiration to become a foresight auditor, BPK is expected to also be able to play the role and assume the position of consultant and provide input/ opinion in the policymaking process (preventive), as well as play a role in the evaluation of government policies through review of reports or performance (enforcement), the latter being of similar nature as the audits BPK has been performing to date.

The purpose of this study is to provide an indepth study of the readiness of legal instruments that form the basis of BPK's authority to realize its role as foresight auditor based on theories on administrative, statutory, and state financial laws. Results from this study are expected to support the government, House of Representatives (Dewan Perwakilan Rakyat, DPR), BPK, and other stakeholders in undertaking their functions. The outcome of this study is expected to feed into 
efforts of the executive and legislative branch of the government, BPK, as well as other relevant institutions to achieve the SDGs' goals.

\section{RESEARCH METHOD}

This normative legal research is done through a study of the legal norms embodied in legislation/regulations related to the use of legal principles in state financial law, statutory law, constitutional law, and administrative law. The focus of attention on normative jurisprudence is the view of law as a practical science that can change circumstances and offer a solution to the potential and concrete problems that exist in society. Normative jurisprudence is directly related to the practice of law which involves two main aspects, namely the formation of law and the application of law (Ibrahim, 2005). Normative legal research focuses on positive law inventory activities, principles and legal doctrines, systematic law, the extent of legal synchronization, comparative law, and the history of law (Muhammad, 2004). This study looks into legislations related to the regulation of state finances and provides an explanation of the meanings of its legal norms and links them with BPK's authority, vision, and mission.

Based on the distribution of types of research mentioned by Hutchinson (as cited in Muhammad, 2004), this type of research is doctrinal research and reform-oriented research. Doctrinal research is research that provides systematic exposure to regulations governing certain legal categories, analyzes the relationship between regulations, explains areas that require obstacles, and even predicts future developments. Doctrinal research seeks to make an inventory of positive law and the discovery of the principles and basis of a positive legal philosophy (Wignjosoebroto, 1974), while reform- oriented research is research that intensively evaluates the fulfillment of current provisions and recommends changes to any regulations that are needed (Muhammad, 2004). The approaches used in this research is the statute approach and conceptual approach. The statute approach was carried out by examining all laws and regulations relating to the legal issues being faced. The conceptual approach moves from the views and doctrines that develop in the jurisprudence (Marzuki, 2016).

Legal materials were collected by following the rules normally applied in normative legal research. Normative legal research is different from empirical legal research, in that normative legal research requires legal material to conduct the study or research. Empirical legal research on the other hand requires data. Collection of legal material for this study was done by examining and researching the amended Constitution of 1945, Law Number 17 of 2003, Law Number 1 of 2004, Law Number 15 of 2004, and Law Number 15 of 2006, as well as other related regulations. An analysis of the legal materials is subsequently carried out and they are then linked with concepts and principles embodied in state financial, administrative, constitutional, and statutory laws, as well as the views/research/writings by legal experts.

\section{RESULT AND DISCUSSION}

\section{Authority of the BPK to Audit State Fi- nances Pursuant to the Amended 1945 Constitution of the Republic of Indo- nesia and the Applicable Laws}

The constitutional authority of the BPK is laid down in Article 23E of the amended 1945 Constitution and is reduced to three "implementing legislations", namely Law Number 17 of 2003, Law Number 1 of 2004 and Law Number 15 of 2004, and Law Num- 
ber 15 of 2006. Derivative constitutional authority is described by Attamimi (as cited in Ridwan, 2007) as a derivative in an administrative position in government, but within the scope of statutory law. Based on the principle of legality in a rule of law state (legaliteitsbeginsel), the authority of the government is conferred by the legislation, which theoretically is obtained through three ways, namely attribution, delegation, and mandate. Regarding statutory law, Attamimi states that legislation can take the form of state regulations at the central or regional levels formed based on the authority of the laws and regulations, both attribution and delegation (Attamimi, 1990).

In line with the views of Attamimi, Ranggawidjaja distinguishes between attribution and delegation authority. Attribution of power (attributie van rechtsmacht), especially attribution of power in the formation of statutory regulations (attributie van wetgevende macht) is often interpreted as granting authority to a particular state agency or institution or official (ambt), both by the legislators of the Constitution and the legislators of the Law. In this case the creation of a new authority for and on behalf of the person authorized. By granting such authority, it will give birth or bring forth a new authority and independent responsibility. Meanwhile, the delegation of authority (delegatie van bevoegdheid) is intended as a handover or delegation of authority (in this case the authority to form legislation) from a state body or agency or official to another state body or agency or official. The authority that originally existed at an agency or institution or official then handed over or delegated that authority (delegans) to the recipient of the authority (delegataris) along with the authority and responsibilities that shifted (Ranggawidjaja, 1998).

Based on those explanations, the definition of management and accountability in state finance given in Article 23E of the amended 1945 Constitution became the basis on which lawmakers construct the state financial legal regime, specifically in order to provide definitions to such terms. The Amended 1945 Constitution does not provide any explanatory articles, thus in compiling the set of state finance laws the legislators must have understood the background situation which gave birth to Article 23E and translated the article into the more concrete form of formal laws.

Kelsen (as cited in Nawiasky, 1948) in his theory stufenbau des Recht theorie states that a legal norm in a country is always multi -layered and tiered, namely that lower norms always apply on the basis of and are sourced from higher norms, and the higher norms are based upon and are sourced from even higher norms, all the way up to the highest norm referred to as the Basic Norm. This theory is then complemented by Nawiasky's theory entitled "Die theorie vom stufenordung der rechtsnormen" which states that in addition to norms being multi-layered and tiered, legal norms of a country also fall into groups. Nawiasky (1948) groups the legal norms of a country into four major groups consisting:

a. Group I : Staatsfundamentalnorm (State Fundamental Norms);

b. Group II : Staatgrundgesetz (Basic Rules/Basic Rules of the State/Constitution);

c. Group III : Formell Gesetz (Formal Law);

d. Group IV : Verordnung and Autonome Satzung (Implementing Rules and Autonomous Rules).

The norm categories are theoretically differentiated into general norms (algemeen) and individual norms as well as between abstract and concrete. From the general or individual and abstract or concrete nature of norms, various norms can be formed with a combination of general-abstract, general-concrete, 
individual-abstract, and concrete-individual nature. From the four types of combinations of the norms, the laws and regulations theoretically contain general-abstract or generalconcrete legal norms. Norms besides that, namely individual-abstract and individualconcrete, are theoretically more appropriate for a determination (beschikking) rather than regulation (regeling) (Attamimi, 1990). In the elucidation of Article 2 paragraph 1 of Law Number 12 of 2011 concerning the Legislations Making, it is stated that "Placement of Pancasila (The Five Norms) as the source of all sources of state law is in accordance with the fourth paragraph of the preamble to the Amended Constitution of the Republic of Indonesia 1945 in the fourth paragraph". Thus, the position of Pancasila according to Nawiasky's theory is as a Staatsfundamentalnorm or State Fundamental Norms and are general also very abstract norms. Meanwhile, the Amended 1945 Constitution is a Staatgrundgesetz given its position as the state constitution and is a derivative of the five norms of Pancasila. The position of the Amended 1945 Constitution is stated in Article 7 of Law Number 12 of 2011 as the highest statutory regulation. The constitution serves as the highest source of law in the hierarchical order of laws and regulations that gives legitimacy to the establishment of state institutions including the regulation on the distribution and separation of powers (Chaidir, 2007), so that state power will be limited by the constitution and the legitimacy of that power can only be obtained from the constitution only.

The derivative legal product of the Amended 1945 Constitution is the laws (formell gesetz). The Constitution is still general in nature and contains abstract norms but these norms are more concrete than those enshrined in Pancasila. Thus, just as it is derived from the Pancasila, the Amended 1945 Constitution provides attribution (attribution derivatives) to laws that carry norms which, although still of a general nature, are more concrete and regeling norms. For this reason, all of the clauses of the Amended 1945 Constitution are accommodated inlaws, including regulations concerning the authority of an institution. The three laws clearly lay down the role of the BPK based on Article 23E of the Constitution. The provisions as contained in the laws reinforce and clarify the task, functions, and authorities in more detail as a derivative of the provisions of Article 23E of the Constitution. Law Number 17 of 2003 and Law Number 15 of 2004 refers to Article 23E in its preamble section. Meanwhile, Law Number 1 of 2004 only cites Article 23 and not Article 23E of the Amended 1945 Constitution in its preamble. However, these three laws together set up the role of BPK as the frontline and the only institution to carry out the task of auditing the management of and accountability in state finances.

One of the general exclamation points of Law Number 1 of 2004 mentions the very important role of $\mathrm{BPK}$, requiring it to be regulated to ensure that the government's financial accountability report can be delivered on time to the House of Representatives (DPR/ DPRD). The above provision reads

“... bearing in mind that the government's financial statements must first be audited by the Supreme Audit Board (BPK) before being submitted to the DPR/DPRD, the BPK plays a very important role in accelerating the delivery of the government's financial statements to the DPR/DPRD".

Thus, these three state financial laws clarify the roles, duties, functions, and authority of BPK in accordance with the mandate of the constitution. Asshiddiqie (2006) views BPK as the DPR's partner in carrying out oversight function (control) with respect to the performance of the government and the application of the State Budget (APBN). Accordingly, results from audits conducted by 
the BPK must be notified to the DPR for further action. The function of BPK financial supervision is a posterior or post-APBN implementation oversight.

The provision also demonstrates that Indonesia is a rule of law state (rechstaat) and not a state based on power (machstaat). Article 1 paragraph (3) of the Amended 1945 Constitution clearly states that Indonesia is a state that abides by the rule of law. Rechtstaat is a concept in Continental European law that can be translated as "state of law", "state of justice" or "state of rights" which means that the exercise of government power is limited by law (Hayek, 2011). The concept of rechstaat has existed for a significant long time, as early as when Plato had a concept whereby good governance of a state must be based on good regulations (law) or referred to as nomoi (Tutik, 2010). Friedrich J. Stahl postulates that rechstaat possess certain characteristics including the protection of human rights, the separation or distribution of power (separate of power), the existence of government based on regulations (wetmatigheid van bestuur), and the existence of administrative justice which free in disputes (Hayek, 2011). The third characteristic of a rechstaat as mentioned above, namely the existence of government based on regulations means that the government in carrying out its duties and obligations must act based on law or legislation (Soemantri, 1992; Nusantara, 1988; Suseno, 1997), and thus it also relates to the second and fourth characteristics that there must be clarity as regards the powers of public officials according to the authority of every institution as determined by the constitution and the laws and regulations below it. In addition, the function of administrative justice as a means of supervising the authority possessed by the government is also one of the features of rechstaat. In the rule of law state concept as state action must be based on law or the law becomes a reference for practices or actions (including authority) exercised by the state or government in undertaking state administration (Tamanaha, 2004). Power exercised within the state must be in line with regulations and strict legal procedures that refer to the Constitution (Zoethout, van der Tang, \& Akkermans, 1993).

Based on the explanation and according to the provisions of Article 1 paragraph (3) of the Amended 1945 Constitution, regulations have a very important role in state administration. The principle of legality requires every exercise of authority by government organs to be based on written law (Berge, 1996) and that actions were taken by the government/public body through state administrators must be in accordance with the authority and legal basis set forth in the laws and regulations. An elaboration of Article 23E of the Amended 1945 Constitution pertaining to the types of audits conducted by the BPK is provided under Article 4 paragraph (1) of Law Number 15 of 2004 jo. Article 6 paragraph (3) of Law Number 15 of 2006, which determines audits of state finances carried out by BPK include financial, audits, and special purpose audits. This is in line with the meaning of the management of state finances and state financial accountability as they are defined in Article 1 subarticle 6 of Law Number 15 of 2004 which states that the management of the state finances constitute the overall action the state financial management official taken by virtue of his position and authority, which includes planning, implementation, supervision, and accountability.

Meanwhile, Article 1 number 7 states that the State Financial Accountability constitute the Government's obligation to carry out the management of state finances in an administratively correct manner, in compliance with the prevailing laws and regulations, efficiently, economically, effectively, and transparently, with due regard to fairness and 
propriety. Thus, based on a faithful interpretation of Law Number 15 of 2004, the meaning of the authority for the management of and accountability in state finances are included in the aspects of input, process, output, and even the outcome of management and responsibility for state finances. Besides the $3_{\mathrm{E}}$ aspects (effective, economical, and efficient) also need to be given attention in the course of an audit in addition to compliance with the laws and regulations and due regard for justice. However, the performance audit has a broader scope than a specialpurpose audit as the former has a comprehensive focus on audit planning, implementation, and output of a project/activity.

Performance audit generally follows one of three approaches: system, results, and problem-oriented approach. An approach is selected based on the conditions and stage of implementation in each country (Rajaguguk, Yatnaputra \& Paulus, 2017). Even INTOSAI has established one of its strategic plans by conducting a performance audit on key government programs that contribute to specific aspects of the SDGs (INTOSAI, 2017). Performance audit will answer whether this process is already effective, efficient, and economic. By performing performance audits, we contribute to the safe and effective use of public funds. This is a precondition for ensuring sound public finances, as required by SDG 8 (Decent Work and Economic Growth) (Demir \& Ellermann, 2019).

Performance audits can help keep track of progress and advocate for government transparency by finding gaps in public services and making realistic recommendations for change. In the case of SDGs, where government accountability and reporting differ across countries, performance audits could improve transparency and rigor (Bruna, 2019). On the one hand, their observations and recommendations will lead to the advancement of policy design and implementa- tion. On the other hand, audits include independent and objective reviews that promote transparency and accountability in the implementation of SDGs. This increases the prestige and reputation of the SDGs at both national and global levels, leading to the strengthening of ownership and the promotion of the agenda (Montero \& LeBlanc, 2019). It is different from the characteristic of the audit with special-purpose. The growth in insight and foresight practices, such as performance auditing, has not necessarily come at the cost of enforcement controls but has indicated that there are more and more different forms of controls (OECD, 2015). In paragraph 18 of BPK Regulation Number 1 of 2017 concerning State Financial Audit Standards (Standar Pemeriksaan Keuangan Negara, SPKN), it is stated that a special purpose audit can be in the form of a compliance audit or an investigation audit (BPK RI, 2017). A special-purpose audit generally compares what is found in the field to what is required by regulations. Thus basically a special purpose audit is regulationoriented.

Law Number 1 of 2004 concerns the submission of financial statements by the government to the BPK in Article 55 and Article 56. BPK will then conduct a financial audit of these financial statements. Other regulatory provisions setting forth the authority of the BPK can be found in Law Number 1 of 2004 which governs is the authority to monitor state losses. This authority is provided under Articles 60 to 67 of such law. Law Number 1 of 2004 does not specifically detail BPK's audit authority, unlike Law Number 15 of 2004 and Law Number 15 of 2006. The latter describes the audit authority more clearly and prescribes the audit procedures or how such an audit can be implemented. Law Number 15 of 2004 details the procedure and mechanism of audits conducted by BPK. In addition, it also regulates the audit planning stage, audit implementation stage, and 
audit reporting stage. Similar to the content of Law Number 15 of 2004, Law Number 15 of 2006 concerns the authority of the BPK including the authority to audit. However, the main focus of the rule in Law Number 15 of 2006 is regarding the BPK as a state organ/ state agency. In that sense, Law Number 15 of 2006 governs the BPK as an institution. For example, it provides for the procedure by which BPK's chairperson, vice chairman, and members are elected.

\section{Analysis of BPK's Authority to Conduct Foresight Audit}

As explained earlier, the scope of audits that can be carried out by BPK is actually quite broad. Lawmakers realize that state finances covers a wide range of aspects and intend the use of state finance to be transparent and accountable both in terms of its management and accountability. Accountability in state finance is the result or output of a state financial management. The use of public funds becomes the object of financial accountability, through which questions regarding the application of such funds will be answered. An audit by BPK would question whether the way the government used certain public funds/ state budget has been per its planned utilization as agreed with the DPR. The result of the audit will then be used by the DPR in performing its governance oversight or budgetary functions (Burhanuddin, 2015).

The state finance management has a wider scope than the state financial accountability. State financial management involves the allocation of a budget to a state financial manager and rules on how the budget is received, the process of managing and applying the funds, and the output and outcomes. An audit of the state finance management will assess whether the funds have been managed properly, effectively, efficiently, and economically. One example according to Mardiasmo (as cited in Minarno, 2010), is a performance audit that evaluates aspects of budget policy (performance policy) and performance budget as the implication of the implementation of the basis on which government budget is prepared using performance-based budgeting.

According to the Accountability Organization Maturity Model developed by INTOSAI

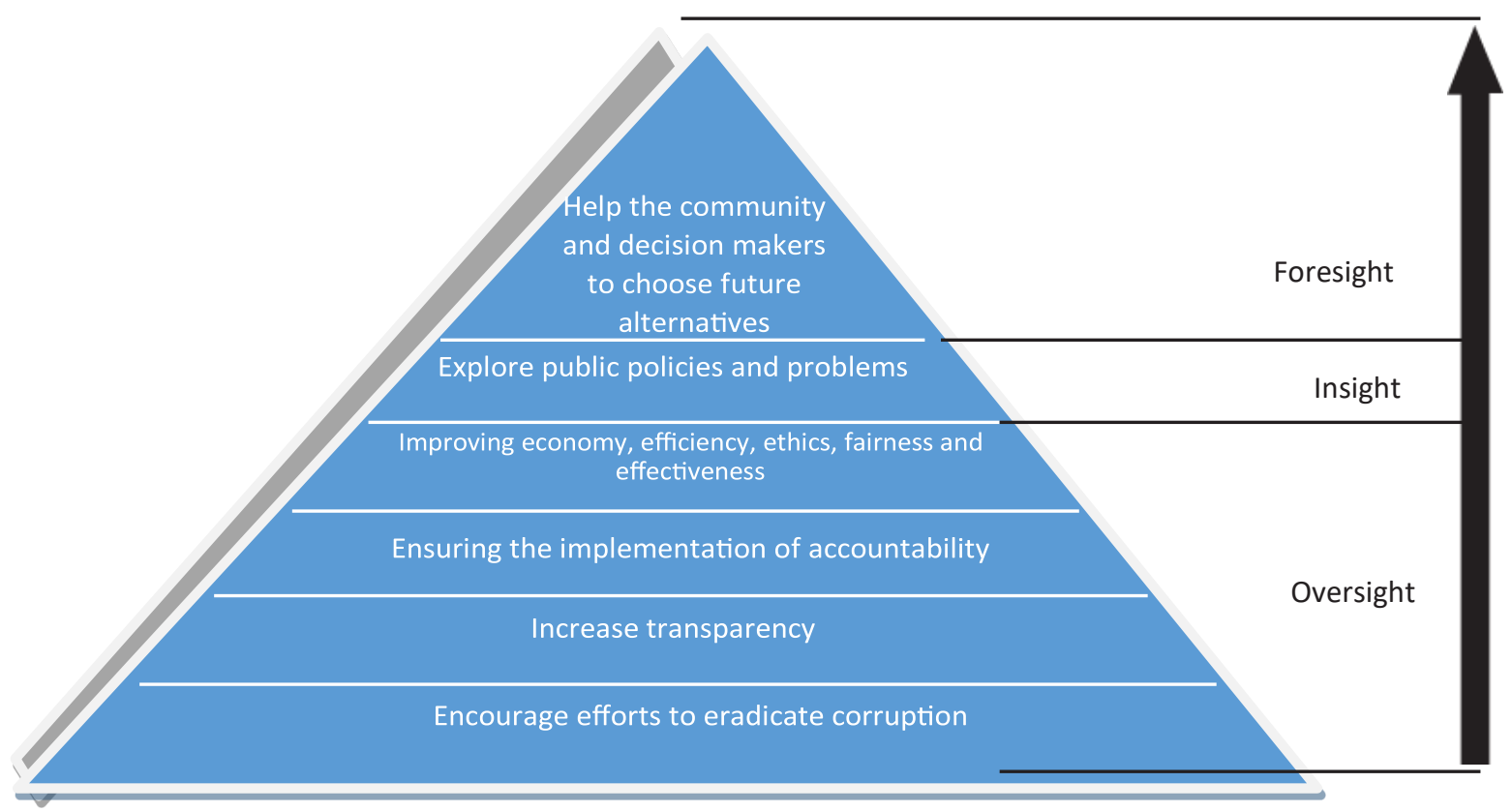

Figure 1. The Accountability Organization Maturity Model (INTOSAI)

Source: processed from GAO's Accountability Organization Maturity Model - Strategic Plan (Renstra) BPK 2016-2020 
as seen in Figure 1, to audit the capacity development, foresight audit level may feature solutions/assistance to the community and decision-makers to choose future alternatives. Audit at the foresight level will have views and ways of thinking to anticipate and be prepared to face both predictable and disruptive developments affecting the position of the government and the state. Drawing upon activities such as continuous scanning and consultation; pattern recognition; analysis of "weak signals"; futures studies; and consensual views. Such audits also examine access to information such as futures reporting; horizon scanning; long-term fiscal projections; scenario planning (OECD, 2015).

As an example, SAI Brazil has conducted a foresight audit level by contributing to medium and long-term policy outcomes by forecasting policy implications and predicting risks. SAI Brazil provides two examples of SAI activities in the form of assessing the government's preparedness to address population aging and workforce management or assessing progress against international commitments to project whether goals would be reached (Bertok, 2018). SAI Brazil looks from a better understanding of the mediumand long-term challenges of improving public administration governance so that its audit work will facilitate sustained changes in public administration. This strategy is important to ensure that SAI Brazil can continue to look forward, whilst the government is more focused on short-term responses to crisis issues. To predict medium and longterm risks that can then be incorporated into its audit programming, SAI Brazil should gene-rate insight and foresight to better understand the current and future audit environment (OECD, 2017).

Article 16 paragraph 2, Law Number 15 of 2004 stipulates that one authority of BPK is to provide recommendations. The performance audit report shall contain audit find- ings, conclusions, and recommendations, although in practice financial statement audits and special purpose audits also contain recommendations to provide solutions to address the audit findings. Recommendation as defined by Article 1 sub-article 12 of Law Number 15 of 2004 is a suggestion from the auditor based on the result of the audit addressed to the authorized person and/or body/agency to take the action and/or improvement. It can be construed that BPK can provide recommendations to the authorized person and/or body to introduce improvements in many aspects.

The most suitable kind of audit to run a foresight audit is a performance audit. By performing a performance audit an auditor can run a comprehensive in-depth audit on many aspects especially the $3 \mathrm{E}$ aspects: effectiveness, efficiency, and economy (costeffectiveness). The law also establishes that auditors not merely audit compliance with regulations but perform a more in-depth audit. Conclusions from a performance audit are expected to be comprehensive and provide maximum results to ensure that the recommendations are given not only bring changes to the output but also create a significant impact. Audit at the foresight level must provide high-quality recommendations as a way to ensure that such recommendations will remain applicable and feasible for 3-5 years (Meijers, 2019). This is one way of implementing a foresight audit by BPK's currently existing authority.

However, this type of audit has not been optimally carried out and is still very resultoriented in terms of how the final budget is assessed. Thus, the orientation of the audit carried out remains on the results and process of budgeting and the government's plan for the long term. Budget planning has never been audited by BPK, despite such planning always being based on government work programs and short, medium, and long term 
government work plans. SAI Brazil recently conducted an audit of the broader budgetary framework. Such audits can be useful inputs for budgetary decision-making and policymaking. From this, SAI Brazil can provide oversight, insight, and foresight audit for more strategic and sustainable budgeting (OECD, 2017).

Currently, BPK is not at that level. In other words, BPK's current work is still at the level of oversight and insight, while at the foresight level it has not produced outputs for society and decision-makers (BPK, 2015). Thus, it can be seen that according to the organizational maturity model of accountability, BPK has not yet reached the foresight level as an auditing body/agency. This condition is compounded by legal instruments that are yet to specifically regulate BPK's authority as a foresight auditor. BPK's position is still at the level of combating corruption; enhancing transparency and assuring accountability. The maturity level is also closely related to the audit's environmental factors, in this case, the interest of that SAI's stakeholders on performance audits just like goods/ services. The quality of the performance audit will improve if there is a large enough demand from BPK stakeholders. If there is great interest from representative bodies and government about how to run a program economically, efficiently, and effectively then the performance audit development process will run smoothly. But as previously disclosed, in relative terms the community, representative bodies, and the government are still focusing their efforts on preparing good financial reports. This does not mean that financial reports are not important, but if financial statements only focus on mere formal legal aspects and pay less attention to outputs and the outcomes achieved by a program/activity, this will not be deemed as sufficiently meaningful (Arfianto, 2010).
As explained in the discussion of the previous point, that the legal instruments governing the authority to audit the management of and accountability in state finance are currently inadequate and need further improvement to provide a broader authority for the implementation of foresight audit. This can be achieved by amending Law Number 15 of 2004 or Law Number 15 of 2006, or by creating implementing regulations that can facilitate BPK's role in promoting and realizing the SDGs. As also already mentioned, the current types of BPK audits include audit financial statements, performance audits, and special purpose audits. The three types of audits are at the oversight and insight audit level. Besides, during discussions of government short-term, medium-term and long-term development plans, BPK regulations are not involved in the process due to BPK's original authority that is confined to examining the management of and accountability in state finance.

The formulation of the National Long-term Development Plan (Rencana Pembangunan Jangka Panjang Nasional, RPJPN), which applies from 2005 to 2025 , is provided under Article 10-13 of Law Number 25 of 2004 concerning the National Development Planning System. It is stipulated that the Head of the National Development Planning Agency (Kementerian Perencanaan Pembangunan Nasional/Badan Perencanaan Pembangunan Nasional, Kementerian PPN/Bappenas) drafts a plan and then together with the Development Planning Forum (Musyawarah Perencanaan Pembangunan, Musrenbang) prepares the RPJP and finalize the draft before it is formalized into law. Concerning the drafting process, the BPK is not given any special authority by law to provide an opinion as a foresight auditor. BPK can only be involved as part of the government during the Musrenbang deliberation session under Article 11 paragraph (1). Similarly, under Article 14-19 on the preparation of the National 
Medium-Term Development Plan (RPJMN), there is no special authority given to BPK to provide an opinion or input in the role of foresight auditor. It can therefore apparent that no clear, concrete and technical provisions on BPK's authority as a foresight auditor have been provided in the laws. Strengthening of legal basis needs to be done by BPK to affirm its function BPK as a foresight auditor as a derivative from its main authority to audit the management of and accountability in state finance per Article $23 \mathrm{E}$ of the Amended 1945 Constitution.

As an audit body, however, BPK has a significant role in overseeing government policies through the results of its audits. As it has been explained the formulation of laws and regulations must adhere to the principles embodied in the higher ranking laws and regulations. The basis of BPK's authority in performing audits of the management of and accountability in state finance are set forth in the provisions of Article 23E of the Amended 1945 Constitution. Thus, as discussed earlier, and bearing in mind the rule of law state (rechstaat) theory, regulations setting forth the authority of the BPK as a foresight auditor needs to be specifically created since the audits normally performed by BPK at the present are limited to oversight and insight level of audit. In the performance of foresight audits, it is necessary to specifically determine and regulate the mechanism and type of examination carried out in such audits as the basis of BPK's authority and to optimize its role in the conduct of foresight audits especially towards the implementation of SDGs by 2030.

Management and accountability responsibilities in state finance entail a broad meaning. Management of state finance includes providing opinions as a consultant in the formulation of future policies. However, BPK's recommendations or input for future policies are currently still given within the corridors afforded to it as an examining body following the constitution. Such opinions are expected to help ensure that the use of state funds in the future will be more targeted, effective, efficient, and cost-effective. Their input and can also contribute to identifying alternative policy options in the future for the Indonesian society and decision-makers, as well as to achieve the SDGs.

Foresight is expensive in terms of time and resources in general and this can be a key factor for emerging economies, in particular (Havas, Atilla, Schartinger \& Weber, 2010). Countries with limited economic capital and research capacity will be immune to the allocation of productive resources to futureoriented activities. They will also lack the capacity to ensure an enduring organizational culture of forward-thinking (GCPSE, 2014). Bearing in mind the foregoing, BPK would have to provide future-oriented audits on state budget plans to allow the government's performance and achievements can be properly realized, especially in the context of attaining the SDGs.

BPK basically has three main functions: operative, judicial, and advisory. The operative function is carried out through audits, supervision, and investigation of control, arrangement, and management of state assets. The judicial function takes the form of authority to initiate action and claim for compensation against state treasurers and other civil servants who, due to their violation of the law (tort) or negligence, have caused financial loss or loss of state assets. BPK's advisory function entails the giving of its opinion to the government regarding the arrangement and management of state finance (Asshiddiqie, 2006). Ashiddiqie states that in carrying out its advisory function the BPK has the authority to render its opinion to the government regarding the arrangement and management of state finance. The advisory function is also an interpretation of Article 
$23 \mathrm{E}$ of the Amended 1945 Constitution. Based on these arguments, it can be said that the drafting of regulations governing BPK as a foresight auditor is still within the corridor of state financial management and does not deviate from the original meaning given in Article 23E of the Amended 1945 Constitution, and thus an explanation of the role of a foresight auditor in the laws can be made. In essence, BPK also has the authority to conduct audits on the management and accountability of state finances and the provision of opinions, considerations, or expert statements is an embodiment of the exercise of the people's sovereignty that they carry (Saidi, 2013). If Ashiddiqie's theory regarding advisory function is linked to the authority BPK presently holds, then it can be understood that BPK has the authority to render opinions. As mentioned in Article 11 of Law Number 15 of 2006 that BPK can submit opinions to the House of Representatives at the various level (DPR, DPD, DPRD), the central government, regional governments, other state institutions, Indonesian central bank (Bank Indonesia), state/local-owned enterprises (Badan Usaha Milik Negara/ Daerah, BUMN/D), public service agencies (Badan Layanan Umum, BLU), government foundations and other bodies/agencies. This ability is necessary given the nature of BPK's responsibility/duty. BPK's opinions are also formed based on the result of their audit reports.

One of the opinions that BPK has rendered concerns the determination of the retail price of subsidized and non-subsidized fuel and the government's accountability in 2019. In its opinion, BPK reveals the problem, namely the impact of determination of retail price (harga jual eceran) on certain fuel types (jenis bbm tertentu), diesel fuel, and assignment-specific fuel types (jenis bbm khusus penugasan) and premium fuel has yet to be reported and accounted for clearly and comprehensively. BPK subsequently provides a discussion, conclusion, and opinions. The problems identified by BPK were based on the results of BPK's audit reports. However, the nature of the BPK's opinion differs from the nature of its recommendations. BPK's recommendations are binding and must be observed according to Article 20 of Law Number 15 of 2004, while BPK's opinions are not binding. This is where the BPK has room to carry out a foresight audit.

In the future, BPK should provide more opinions on various aspects and matters and thereby give the Government, DPR, DPD, DPRD, or the decision-makers several alternatives to choose from as there is no obligation to implement all of the opinion given. From BPK's opinions, decision-makers can acquire information, consideration, or reasoning. They can decide the best solution and will get the best possible result in the future. The foresight function of the BPK where it can offer its opinion involves the selection of public policies (policy setting) in program development, which also requires a stakeholder engagement strategy to make sure that BPK's opinion is understood, trusted, and optimally utilized by the government and other stakeholders (Pramono, 2016). This is the most likely way BPK can pursue such a function based on its current authority.

The urgency of BPK's role as a foresight auditor at present and in the future is very high. Currently, many auditees have a strong understanding of accounting practices, so that the entity can prepare adequate financial reports. With this trend, it is likely that in the future more auditees will succeed in obtaining unqualified opinion. With the increasing number of entities that understand the appropriate methods for preparing sound financial reports and a more orderly recording process on the part of these entities, the BPK's vision and mission to promote governance and accountability of state finances will gradually be achieved. Auditing will also fundamentally 
change: at some point, digitization and the use of artificial intelligence will take over the audit of financial information, so that the auditor's position will focus more on auditing non-financial/narrative information. These changes will require a variety of skills, such as the study of the truth of complex science data/statements made in sustainability reports (Kalar, 2019). Therefore, BPK needs to be prepared to carry out its role in the future as a foresight auditor. It is hoped that in the future the BPK will not play a major role in reviewing output, but will begin to make improvements to the input process, work plans, and work program formulation.

SAI also provides a forward view by assessing the readiness of the government to deal with complex problems in the long term (OECD, 2015). Thus, the vision and mission for the future are to ensure that the management of state finances and the efforts of the state to realize social justice for all Indonesian people can run effectively, efficiently, and economically in a just, sure and profitable manner through careful audits. In the future, BPK's authority regarding foresight audits is expected to be a concern. The authority of BPK must be strengthened to further improve the quality of good governance through amendments to Law Number 15 of 2004 or Law Number 15 of 2006 or by establishing implementing regulations.

\section{The Role of BPK as Foresight Auditor in Accelerating the Achievement of the SDG Goals}

The aforementioned current role of BPK is still at the audit level as an oversight and insight entity based on the Accountability Organization Maturity Model. The role of BPK as an oversight auditor is manifested by the performance of audits aimed at ensuring that government entities have carried out good governance of state finances, under existing accounting standards, as well as complying with statutory provisions. BPK also plays a role in preventing deception, fraud, waste, misuse, and mismanagement in the management of and accountability in state finance. Oversight function is carried out by encouraging the eradication of corruption, increasing transparency and accountability, as well as increasing the value of certainty, costeffectiveness, efficiency, ethics, fairness, and effectiveness. Meanwhile, BPK's role as an insight auditor is undertaken by providing opinions related to programs, policies, and performance. It would also then suggests best practices as guidelines and standards that can be applied. It also suggests institutional efforts in improving cross-sectoral relations in government (the whole of government) as well as in improving the suitability of government and non-governmental partners that are better and more suitable for achieving important outcomes for the country and society. This insight function is carried out by deepening public policies and problems (Renstra BPK 2016-2020).

Along with BPK's efforts to become a foresight auditor, at the current level of insight and oversight BPK can also encourage the achievement of SDGs through environmental audits or environmental perspectives audits. Sustainable development is a concept that combines the needs of the present without reducing the ability of future generations to be able to meet their own needs which in essence lies in economic growth, social inclusion, and environmental protection (Sadiq \& Mushtaq, 2015). Sustainable development is often concerned with emphasizing the longterm outlook and linking the natural, social, and economic aspects. The cross-sectoral approach to silos-breaking can be seen in some of the INTOSAI and SAI events on SDGs (Niemenmaa, 2019). Environmental audit is one of the most important contributing factors in carrying out sustainable development (Djajaputra, 2001). However, environmental auditors need to pay attention 
to academic qualifications and professionalism or experience in conducting environmental audits (Atherton, 1994). Auditors should have a working knowledge of the applicable regulations. This knowledge can be acquired in several ways, through courses, textbooks, and the review and application of audit engineers or protocols (Wilig, 1995).

BPK can conduct audits with a sustainable development approach to financial audits, performance audits, and special purpose audits. In conducting financial audits, BPK can carry out an examination of the financial statements and review the items and link them with existing environmental problems, such as environmental issues related to reclamation permits. The BPK can check whether the reclamation permit granted is in accordance with the provisions and considers the environment. In addition to reclamation permits, the granting of licenses, especially related to environmental permits, must basically be granted in accordance with the applicable legislation and require the publication of studies, environmental impact assessment (Analisis Mengenai Dampak Lingkungan, AMDAL), and follow the mechanism for obtaining permits. Meanwhile, special purpose audits and environmental audits can also be carried out such as those related to compliance with the management or protection of the environment. For a performance audit, based on document searches, BPK has conducted three audits that are directly related to sustainable development.

One example of carrying out environmental audits or audits with a perspective of sustainable development carried out by BPK is the implementation of SDG number 14 (Life Below Water - Protection and sustainable use of oceans, seas, and marine resources) by conducting audits related to marine conservation, illegal fishing, and destruction of coral reefs. BPK has also carried out an audit of maritime affairs in the Province of Nusa
Tenggara Timur (NTT) using comprehensive methods, implementation and results. The use of criteria sources from regulations, journals, experts, etc., plus audit evidence in the form of testimonials, documentaries, analysis of area calculations, satellite mapping, checking of waste, and geo-tagging (Simanjuntak, 2019). This audit is titled Performance Audit of the Effectiveness of Marine Development Efforts to Support Sustainable Development in Fiscal Year 2015 through Semester I of 2018 at NTT Provincial Government and Other Related Agencies (Pemeriksaan Kinerja atas Efektivitas Upaya Pembangunan Kelautan Untuk Mendukung Pembangunan Berkelanjutan TA 2015 s.d. Semester I 2018 pada Pemerintah Provinsi NTT dan Instansi Terkait Lainnya) (BPK, 2019). The other two performance audits are titled Performance Audit of the Effectiveness of Tourism Programs and Activities to Support Sustainable Development in Fiscal Year 2014 through Semester I of 2017 at the West Manggarai Regency Government in Labuan Bajo (Pemeriksaan Kinerja atas Efektivitas Program dan Kegiatan Kepariwisataan dalam Mendukung Pembangunan Berkelanjutan Tahun Anggaran 2014 s.d Semester I 2017 pada Pemerintah Kabupaten Manggarai Barat di Labuan Bajo) (BPK, 2018a) and Performance Audit of the Preparedness for Implementation of Sustainable Development Goals in Indonesia at National Development Planning Agency, Statistics Indonesia (Badan Pusat Statistik, BPS), Ministry of Finance and Other Related Agencies (Pemeriksaan Kinerja atas Kesiapan Implementasi Tujuan Pembangunan Berkelanjutan di Indonesia pada Bappenas, Badan Pusat Statistik, Kementerian Keuangan dan Instansi Terkait Lainnya) (BPK, 2018b).

In its Performance Audit of the Preparedness for Implementation of Sustainable Development Goals in Indonesia, BPK has revealed several important things that mechanisms to ensure the sustainability of SDGs programs 
across government cycles need to be improved. Also, policies on budget and expenditure need to be established in promoting the quality of government spending and the disaggregation of the statistical data at the city and municipal level has not been able to be generated. From these important things, BPK recommends that the Minister of National Development Planning work together with the Minister of Home Affairs to formulate long-term and medium-term planning mechanisms that would ensure the sustainability of national strategic programs/ SDGs across government cycles. Moreover, the Minister of National Development Planning works with the Minister of Finance to draft a presidential regulation on quality budget and expenditure and the Statistics Indonesia to refine the draft Presidential Regulation on One Data to affirm the position of Statistics Indonesia as the recognized authority for a statistical referral to coordinate all statistics resources in Indonesia. Besides, BPK recommends that Statistics Indonesia strengthen the coordination among statisticians in providing reliable and highquality data (BPK, 2018b).

These performance audits focus on examining the implementation of sustainable development from an environmental perspective. With the performance audit, BPK hopes to accelerate the achievement of sustainable development by providing recommendations for their improvement. Further BPK hopes that the relevant entities can improve their performance to get the best result now and in the future. These entities also can take advantage of BPK's recommendations as material for changes or improvements in other sectors related to the SDGs. BPK has always wanted to push these related entities through recommendations and suggestions for improvement. Aside from the above, the BPK can also provide opinions on the current implementation of the SDGs and preparation for achieving the SDGs in 2030. SDGs may be used to illustrate the financial importance of sustainable action to organizations and society at large (Arnold \& Szenci, 2019). Financing efforts to achieve the SDGs would be vital to their progress in ending injustice, protecting the environment, and creating a fairer and more sustainable society. SAIs have an important role to play in the audit of SDG-related finance (Vries, 2019). With this in mind, BPK's recommendations and opinions as mentioned above are very important in its role as a foresight auditor under its current authority.

Other problems found based on the results of SDG-related audits are unclear/overlapping responsibilities, lack of coordination between main stakeholders at sub-national levels and the national, absent or deficient policies or strategies, insufficient assessment of the environmental/social effects of governmental policies and programs, lack of analysis (economic, social and environmental) of supporting decisions, lack of long-term planning to implement policies and programs, inadequate financial management of policies and programs, lack of enforcement of domestic legislation, deficient monitoring and reporting systems and lack of data for decisionmaking (Dutra, 2016). From these problems, SAI must prepare an appropriate SDGs audit strategy. To improve the quality of the SDGs' audit recommendation, SAI can exchange information and audit strategies. SDGs have become a common commitment and common goal of most countries in the world so that every country is obliged to do their best to achieve SDGs, including in the field of auditing.

The problems of sustainable development are strongly interlinked, requiring integrated strategies and mutually related factors. The SDGs must be enforced by each country, but each country must recognize its own actions concerning the objectives (Koopman, 2019). The efforts and commitment of a country in 
achieving the SDGs can be monitored from government attention and policies related to SDGs starting from planning, implementation, reporting to monitoring such as auditing the implementation of the SDGs. The SAI of a country should be provided with a legal basis for conducting SDG audits. In Indonesia, the duties and roles of the BPK are following the mandate of the Amended 1945 Constitution, the state's objective in the form of people's welfare, and the government's commitment to achieving the SDGs. It is necessary to provide adequate legal support such as in the form of implementing regulations for BPK to play a role in encouraging and realizing the achievement of the SDGs.

Based on historical interpretation and constitutional interpretation, BPK has a role as an auditor of the management of and accountability in state finance. From the formation of the institution through Government Decree Number 11/OEM dated December 28, 1946, titled the Formation of the Supreme Audit Board, BPK has sole authority to audit the management of and accountability in state finances based on the Indische Comptabiliteitswet (ICW) - Staatsblad Year 1925 Number 448 and Instructie en Verdere Bepalingen Voor de Algemene Rekenkamer (IAR) - Staatsblad Year 1933 Number 320. From its inception to the present, BPK has always been positioned as one of the state's High Institutions, as in auditing the state financial management and accountability, $\mathrm{BPK}$ is required to be independent, free, maintain its integrity, and professionalism. BPK is expected to stand as an external government institution and not be in three branches of power, namely the executive, legislative, and judiciary because BPK examines the three branches of power from outside as the government's external auditor. In other words, BPK is not actively involved in carrying out government functions. However, based on Asshiddiqie's concept, BPK can provide input (advice) both through the re- sults of the examination and request for opinions/views from the government on a policy. Government policies will always be audited and reviewed by BPK, especially those relating to the achievement of the SDGs. Efforts that can be made by BPK within its current scope of authority are to provide recommendations for financial audits, performance audits, and special purpose audits as well as providing opinions to the related government institutions. Other than that, the provision of recommendations by BPK through further audits related to SDGs would encounter some obstacles.

The determination of INTOSAI to establish the audit scope depends on individual ability and choice and can cover national or subnational levels. While one of the key phases of the planning performance audit is the creation of the audit scope, INTOSAI guidance offers very little explanation of the phases. The preparation of SDGs to be audited requires the incorporation of economic growth, social and environmental sustainability, the participation of multi-sectoral entities, and collaboration between the government and private sectors. Developing audit scope is therefore a very challenging process. Data is another obstacle found in the discussion on auditing readiness of SDGs. Data challenges are varied, ranging from availability, scattered, inconsistency, access to data, data collection, processing, and tabulation to the presentation. In its guideline, INTOSAI reported issues on data availability in 11 SAIs, while issues related to data collection have been experienced by three SAIs. While metadata and SDGs databases are available online, national data is a real challenge.

Obstacles like this should therefore be one of BPK's concerns in executing audit plans that involve the SDGs. BPK needs to do more SDG audit preparation studies to carry out audits with optimal results or outputs. BPK as an audit institution is part of a country's 
national audit system. Audit institutions in many countries are part of a country's national audit system. Audit institutions in many countries are now providing governments with an impartial internal oversight process that encompasses the entire spectrum of government operations and services. Some countries may have special development roles within their audit institutions to resolve issues of sustainable development. A significant innovation in audit institutions is the movement towards the formation of commissioners working on behalf of future generations. For example, a 'Future Generations Commissioner' was recently created in Wales under the revolutionary 'The Wellbeing of Future Generations (Wales) Act'. Hungary has been a leader in this respect in its efforts to establish an Ombudsman for Future Generations (UNDG, 2017).

One of the studies on the preparation of the SDGs audit was carried out by Tribunal de Contas da Uniao (SAI Brazil) together with The Organization of Latin American and Caribbean Supreme Audit Institutions (OLACEFS) countries in 2017. From this studies, SAI Brazil describes the steps that need to be considered in carrying out SDGs audits, namely integration and cross-cutting, long term thinking, identification of common causes, results based oriented and integrated perspective of government/whole government (OLACEFS, 2017). SAIs may also assist the introduction of SDGs in four ways, as also defined by the INTOSAI in 2016:

a. They can track performance and audit how a country implements the 2030 agenda at all levels of government;

b. SAIs will promote good governance by ensuring overall governance coordination, coherence, and strong stakeholder participation;

c. By encouraging accountability and transparency, SAIs can also serve as role models for good governance, enhancing the performance of the country in accordance with SDG 16: Peace and Justice Institutions;

d. SAIs will enhance national readiness for SDGs by improving tracking, evaluation, and reporting arrangements (Bonturi, 2019).

From these steps, it can be seen that audits relating to the SDGs must be well prepared. It can also be concluded that long term thinking and integrated perspective of the government are very important factors. An integrated perspective of the government means that BPK cannot achieve the SDGs alone. BPK needs the whole of government, namely that all government entities to work together to achieve these goals. This task also needs the involvement of local governments because local governments have important roles in implementing policies related to SDGs in their respective regions. For example, local governments in Indonesia have developed local action plans (Rencana Aksi Daerah, RAD). However, the implementation of this regional action plan must be continuously monitored and observed how progress has been made by the local government. Based on data in Europe, 65 percent of the 169 SDGs cannot be done without consultation or participation of regions and cities (local governments). Indeed, while most public policies and investments are shared by all levels of government, the majority of total public investment in the EU comes from subnational authorities (Abramavicius, 2019).

Supervision of the implementation of SDGs commitments at all levels of government is the task of SAI. SAIs, for example, can be instrumental in ensuring that national governments are placing these international commitments in their agendas and pursuing them with transparency and accountability (Dutra, 2016). SAI (BPK) should also acquire trust to affect the overall evolution of the implementation of SDGs at different levels of government (IDI, 2019) and all of the entities 
must understand the implementation of achieving the SDGs and also must commit to improving performance together with BPK through recommendations or opinion given by BPK. Apart from cooperating with other related entities, BPK also needs to encourage other stakeholders, such as parliamentarians and civil society groups, to build synergies in attempts to keep governments accountable (IDI, 2019).

States, people, and companies must also all be active in the execution of the objectivesno party can accomplish enough on its own. As states implement policies and legislation to provide adequate framework requirements for the required reform, educational institutions are called upon to provide information and skills to learners of all ages in order to foster sustainable development (Heim, 2019). For example, Bundesrechnungshof (SAI Germany) expects to play a role in achieving the SDGs through several ways, one of which is to publish audit findings - as far as possible and available to the general public. In this way, it is hoped that the community will participate in strengthening the achievement of the SDGs in German society (Demir \& Ellermann, 2019). Also, in the Organization of Latin American and Caribbean Supreme Audit Institutions (OLACEFS) regional, they want to publish their consolidated report on SDG 5 (Gender Equality) as a means of cooperating with civil society organizations to foster a mutually beneficial relationship and increase the visibility of audit results and findings for stakeholders. They assume, for example, that their SAIs cannot continually track all the results of the audit in their reports. Instead, provided that the results of our studies could be used as a method to keep governments accountable, public society may find the reports helpful in their advocacy process (Pulgar, 2019). Civil society activism has played a crucial role in pushing forward the 2030 Agenda and the SDGs. Civil society groups should play and play a major role in the implementation process as watchdogs, brokering, and developing alliances, proposing, and taking action. Monitoring and reporting are essential roles within the overall mosaic of monitoring and reporting activities, by various civil society organizations as well as institutions such as the departments of the European Union (EU) and the supreme audit institutions (Niestroy, 2019). This shows that the roles of various parties are needed to achieve the SDGs.

Each level of government, therefore, decides how to achieve these ambitious goals in the light of its own national history, and the evaluation of the country's success is purely voluntary. This means that the implementation of the SDGs will eventually rely on people who will have to remind their representatives of their duties and then hold them accountable. Constructive transparency - which means celebrating performance and seeking ways to speed it up - is of the utmost importance in this respect. Achieving the SDGs would require the participation of all stakeholders, at all levels, all over the world. A full appreciation of the role of regions and cities in localizing the SDGs - and their subsequent empowerment - would increase the probability of timely achievement of the SDGs. These stakeholders are undeniably an integral part of the governance and implementation of the SDGs, leaving no one - and no territory - behind (Abramavicius, 2019). The other point is long term thinking. This is foresight thinking because in conducting an SDGs audit plan, SAI is expected to be able to think about future or long-term thinking. On the one side, SAIs should ask their governments if their sustainability aspirations involve forward-looking thinking and longterm risk assessments. On the other hand, SAIs should ask themselves what is the timeframe against which their evaluations and recommendations are made (Niemenmaa, 2019). 
BPK's auditor must have a foresight vision to implement foresight audits, namely providing alternative solutions and providing policies for the future. Meanwhile, the role as foresight auditor as expected, is that the BPK can play a role in providing future review by paying attention to the long-term implications/effects of government decisions/ policies and identifying key trends and challenges that constitute the state and society before it emerged as a crisis. Foresight function can be done through the exercise of BPK's authority to render opinions on the selection of public policies (policy setting) in development programs (Pramono \& Hendarto, 2017). In other words, BPK has a central role as a government consultant and government partner to assist in determining future policies in the whole of government concept. This function is expected to be able to help the Indonesian society and the decisionmakers to choose future policy alternatives. This function can be done by giving opinion by BPK related to the selection of public policies (setting policies) in development programs (BPK, 2015). Thus, the foresight audit can be a solution to examining budget planning. Foresight work focuses on the main business processes of an enterprise. It aims to have an impact on a variety of levels, such as the policy, the collection of audit topics, or the creation of the right future capacity and expertise. Foresight is used in important decision-making areas, such as the MultiAnnual Approach, Annual Work Planning, the further improvement of the audit framework applied, and the preparation of reports (Meijers, 2019).

Government policy will determine the use of the budget each year in the long run. To accelerate the achievement of the SDGs, apart from providing recommendations based on the results of further audits of the SDGs, providing BPK opinions and adding authority from the revision of Law Number 15 of 2004 or Law Number 15 of 2006 specifically regulating the implementation of foresight audits or make implementing regulations for BPK to play a role in encouraging and realizing SDGs. Other than that, BPK must also include the focus on accelerating SDGs in its audit programs so that it is in line with the government's goal to achieve the SDGs by 2030. Some points to accelerate SDGs are focus on priority areas, integrated approach, including synergies and trade-offs, bottleneck assessment, financing and partnerships, and measurement (UNDP, 2015). All of these methods to accelerate the achievement of SDGs need to be given a focus since the 2016-2020 BPK strategic plan (Renstra BPK 2016-2020) has not paid special attention to the acceleration in achieving the SDGs. The achievement of the SDGs certainly cannot be done instantly, but it must be prepared and started early so that it can be carried out immediately and can be achieved as a whole by 2030. Development activities will be determined by the final goal to be achieved.

\section{CONCLUSION}

In the case of a rule of law state, a principle that must be adhered to is that governance and the exercise of all actions/deeds/ authority by the government must be based on laws and regulations. Article 1 paragraph (3) of the Amended 1945 Constitution specifically states that Indonesia is a rule of law state. The authority possessed by BPK is one that is also held by other public or government entities that are governed by Article 23E of the Amended Constitution. However, BPK's authority to review at the foresight level still has no concrete outcome. According to the Maturity Model of the Accountability Organization, foresight audit level has one example of production in the form of offering solutions/assistance to the community and decision-makers in selecting future alternatives and will have viewpoints and ways of 
thinking to foresee and be prepared to meet both predictable and unpredictable changes impacting the role of the government and the state. At the foresight level, SAI contributes to medium-and long-term policy outcomes by forecasting policy consequences and forecasting risks. However, with its current authority, BPK can only carry out a foresight audit within the confines imposed by the existing regulatory framework, namely to make recommendations and provide opinions.

The urgency of BPK's role as a foresight auditor presently and in the future is also great. BPK's role in the future must therefore be shaped towards it becoming a foresight auditor. It is also hoped that BPK's future auditing powers will become a concern in the future and strengthen its authority to take further steps in raising good governance standards. Performance audits are the most effective audit method for conducting foresight audits and are expected to provide useful input for financial decision making and policy making. A Foresight Audit authority will be very important in accelerating the achievement of the SDGs by 2030. BPK has three primary functions: operative, judicial, and advisory. In its advisory role, it draws the government's attention to issues relating to the organization and management of state finance. BPK has submitted opinions to the government. Giving opinions is distinct from giving advice. BPK recommendations are binding and must be adhered to according to Article 20 of Law 15 of 2004, while BPK opinions on the other hand are not binding. In the future, BPK should render more opinions on different aspects and issues to the Government, DPR, DPD, and DPRD to allow decision-makers to have the opportunity to select possible alternatives as there is no requirement for them to follow the opinions expressed. Decision-makers can extract knowledge, consideration, or reasoning from BPK's opinions and thereby arrive at the right solution to have the best possible outcome in the future.

There will still be barriers/problems based on the results of the SDG-related audit which has been implemented by several SAIs. The SAI must plan an appropriate audit strategy to enhance the consistency of the audit recommendations for SDGs, information, and audit techniques can be shared between SAIs. BPK also needs to concentrate on accelerating SDGs attainment in its audit programs so that they are in line with the government's goal of achieving the set targets by 2030. More studies in the incorporation of SDGs in the audit planning process need to be carried out by BPK to allow it to carry out audits with full outcomes or outputs. To realize the conditions required by the SDGs, BPK requires a whole concept of government, namely the awareness of all agencies to work together to achieve the objectives of the SDGs. This challenge also needs to include local governments, as local governments have an important role to play in enforcing SDG policies in their respective regions. All of the related entities must recognize the application of the SDGs and must also commit to enhancing performance along with BPK through recommendations or opinions from BPK.

BPK auditors must have the foresight for the execution of foresight audits, namely the provision of potential solutions alternative future policies. The foresight role can be performed by enforcing its authority to render opinions on the selection of public policies (policy setting) in development programs. It is definitely not possible to achieve the SDGs within a short period of time. Efforts must instead be planned right now or very early so that they can be carried out as soon as possible and can be entirely completed by 2030 . BPK will play a role in promoting, monitoring, and looking ahead into the future based on its authority, so that policies implemented 
by decision-makers are correct and drive progress in achieving the SDGs. Thus, concerning the legal basis for conducting foresight audit towards accelerating the achievement of the SDGs, the legal instruments as they currently exist relating to authority over the management and transparency of state finances are currently adequate, but still require improvement to establish a broader authority to apply foresight audit in achieving such goals. A solution can be created by increasing the authority to conduct foresight audit through an amendment to Law Number 15 of 2004 or Law Number 15 of 2006 and/or bypassing implementing regulations that would provide a legal basis for the BPK to play a role in promoting and implementing the SDGs.

\section{REFERENCES}

Abramavicius, A. (2019). How to ensure SDGs are implemented in an accountable way at the regional and local levels. European Court of Auditors Journal, 3, 19-22. Retrieved from https://www.eca.europa.eu/ lists/ecadocuments/journal19_03/ journal19_03.pdf

Arfianto, A. D. (2010). Studi perbandingan audit kinerja pada Badan Pemeriksa Keuangan dengan lembaga pemeriksa keuangan negara lain. (Unpublished master's thesis). Universitas Indonesia, Jakarta, Indonesia.

Arnold, V., \& Szenci, K. (2019). How external auditors can help corporates report on non-financial information and meet sustainable development goals. European Court of Auditors Journal, 3, 65-75. Retrieved from https:// www.eca.europa.eu/lists/ ecadocuments/journal19_03/ journal19_03.pdf

Asshiddiqie, J. (2006). Sengketa kewenangan konstitusional lembaga negara. Jakarta: Sekretariat Jenderal dan Kepaniteraan Mahkamah Konstitusi RI.
Atherton, P. (1994). Environmental information law policy \& experience. London: Cameron May Ltd.

Attamimi, A. H. S. (1990). Peranan Keputusan Presiden RI dalam penyelenggaraan pemerintahan negara: Studi kasus analisis mengenai Keputusan Presiden yang berfungsi pengaturan dalam kurun waktu Pelita I-Pelita $I V$. (Unpublished doctoral dissertation). Universitas Indonesia, Jakarta, Indonesia.

Berge, J. B. J. M. T. (1996). Besturen Door De Overheid. Deventer: W.E.J. Tjeenk Willink.

Bertok, J. (2018). Supporting Brazil's Federal Court of Account: Insight \& foresight for better governance. Brazil: OECD.

Bonturi, M. (2019). The role of SAIs in delivering accountability and success for the UN SDG. European Court of Auditors Journal, 3, 56-60. Retrieved from https://www.eca.europa.eu/ lists/ecadocuments/journal19_03/ journal19_03.pdf

BPK RI. (2015). BPK's Decree Number 7 Year 2015 concerning BPK's Strategic Plan for Year 2016-2020 (Keputusan BPK Nomor 7 Tahun 2015 tentang Rencana Strategis Badan Pemeriksa Keuangan Tahun Anggaran 20162020). Retrieved from https:// www.bpk.go.id/assets/files/ attachments/ attach_post_1457317017.pdf

BPK RI. (2017). BPK Regulation Number 1 Year 2017 concerning State Financial Audit Standards (Peraturan BPK RI Nomor 1 Tahun 2017 tentang Standar Pemeriksaan Keuangan Negara). Retrieved from https://www.bpk.go.id/ page/standar-pemeriksaan-keuangan -negara

BPK RI. (2018a). Laporan hasil pemeriksaan kinerja atas efektivitas program dan kegiatan kepariwisataan dalam mendukung pembangunan berkelanjutan tahun anggaran 2014 s.d. semester I 2017 pada Pemerintah Kabupaten Manggarai Barat di Labuan Bajo. Jakarta: BPK RI.

BPK RI. (2018b). Laporan hasil pemeriksaan kinerja atas kesiapan implementasi tujuan pembangunan berkelanjutan 
(Sustainable Development Goals) di Indonesia pada Bappenas, Badan Pusat Statistik, Kementerian Keuangan dan instansi terkait lainnya. Jakarta: BPK RI.

BPK RI. (2019). Laporan hasil pemeriksaan kinerja atas efektivitas upaya pembangunan kelautan untuk mendukung pembangunan berkelanjutan tahun anggaran 2015 s.d. semester I 2018 pada Pemerintah Provinsi NTT dan instansi terkait lainnya. Jakarta: BPK RI.

Bruna, G., Fox, C., Lynch, A., Torres, E. (2019). The Sustainable Development Solutions Network - Contributing to SDG Development, Implementation and Monitoring. European Court of Auditors Journal, 3, 80-85. Retrieved from https:// www.eca.europa.eu/lists/ ecadocuments/journal19_03/ journal19_03.pdf

Burhanuddin, N. (2015). Hukum keuangan negara. Jakarta: Total Media.

Chaidir, E. (2007). Hukum dan teori konsitusi. Yogyakarta: Kreasi Total Media.

Demir, A., \& Ellermann, B. (2019). Sustainability: A (new) challenge for Supreme Audit Institutions?. European Court of Auditors Journal, 3, 36-39. Retrieved from https:// www.eca.europa.eu/lists/ ecadocuments/journal19_03/ journal19_03.pdf

Djajaputra, G. (2001). Aspek yuridis peranan audit lingkunan dalam pembangunan berkelanjutan. (Unpublished doctoral dissertation). Universitas Indonesia, Jakarta, Indonesia.

Dutra, P. H. (2016). SDGs audit results framework. International Jourmal of Government Auditing. Retrieved from http://intosaijournal.org/sdgsaudit-results-framework/

Global Centre for Public Service Excellence (GCPSE). (2014). Foresight as a strategic long-term planning tool for developing countries. Retrieved from https://www.undp.org/content/ dam/undp/library/capacitydevelopment/English/Singapore\%
20Centre/GPCSE_Foresight.pdf

Hadjon, P. M. (1997). Pengkajian ilmu hukum. Paper presented at Penataran dan Lokakarya Sehari Menggagas Format Usulan dan Laporan Penelitian Hukum Normatif, Malang, Indonesia.

Havas, A., Schartinger, D., \& Weber, M., (2010). The impact of foresight on innovation policy-making: Recent experiences and future perspectives. Research Evaluation, 19(2), 91-104.

Hayek, F. A. (2011). The constitution of liberty. Chicago: University of Chicago Press.

Heim, K. H. (2019). From Millenium Development Goals to Sustainable Development Goals - just more of the same? European Court of Auditors Journal, 3, 07-11. Retrieved from https://www.eca.europa.eu/lists/ ecadocuments/journal19_03/ journal19_03.pdf

Hoelman, M. B., Parhusip, B. T. P., Eko, S., Bahagijo, S., \& Santono, H. (2015). Panduan SDGs untuk pemerintah daerah (kota dan kabupaten) dan pemangku kepentingan daerah. Jakarta: International NGO Forum an Indonesian Development.

Ibrahim, J. (2005). Teori dan metode penelitian hukum normatif. Malang: Bayumedia Publishing.

INTOSAI Development Initiative (IDI). (2019). Independent oversight for effective, accountable, and inclusive institutions: Strengthening the role of supreme audit institutions in SDG implementation and review. Paper presented at the 6th Asia-Pacific Forum on Sustainable Development, Bangkok, Thailand. Retrieved from https://www.partners-for-review.de/ wp-content/uploads/2020/o3/ Summary-of-APFSD-side-event-onSAI-role-in-SDG-implementationreview-FINAL.pdf

INTOSAI. (2017). Strategic plan 2017-2022. Austria: INTOSAI. Retrieved from https://www.intosai.org/fileadmin/ user_upload/EN_INTOSAI_Strategic_Plan_2017_22.pdf

Kalar, M. (2019). ECA sustainability reporting forum - time for the truth, the 
whole truth and nothing but the truth. European Court of Auditors Journal, 3, 103-107. Retrieved from https://www.eca.europa.eu/lists/ ecadocuments/journal19_03/ journal19_03.pdf

Koopman, G. J. (2019). Mainstreaming the SDGs in EU policies and reporting the results. European Court of Auditors Journal, 3, 15-18. Retrieved from https://www.eca.europa.eu/lists/ ecadocuments/journal19_03/ journal19_03.pdf

Law of The Republic of Indonesia Number 17 of 2003 concerning State Finances (Undang-undang Nomor 17 Tahun 2003 tentang Keuangan Negara). Retrieved from https:// www.kemenkeu.go.id/sites/default/ files/pdf-peraturan/ Law\%20No\% 2017\%20of\%202003.pdf

Law of The Republic of Indonesia Number 1 of 2004 concerning State Treasury (Undang-undang Nomor 1 Tahun 2004 tentang Perbendaharaan Negara). Retrieved from https:// www.kemenkeu.go.id/sites/default/

files/pdf-peraturan/ UU\% 20NOMOR\%201\%20TAHUN\% 202004.pdf

Law of The Republic of Indonesia Number 15 of 2004 concerning The State Financial Management and Accountability Audit (Undang-undang Nomor 15 Tahun 2004 tentang Pemeriksaan Pengelolaan dan Tanggung Jawab Keuangan Negara). Retrieved from https://www.bpk.go.id/assets/files/ storage/2013/12/

file_storage_1386158654.pdf

Law of The Republic of Indonesia Number 25 of 2004 concerning The National Development Planning System (Undang-undang Nomor 25 Tahun 2004 tentang Sistem Perencanaan Pembangunan Nasional). Retrieved from http://www.dpr.go.id/ dokjdih/ document/uu/26.pdf

Law of The Republic of Indonesia Number 15 of 2006 concerning The Audit Board (Undang-undang Nomor 15 Tahun 2004 tentang Badan Pemeriksa Keuangan). Retrieved from http:// www.bpk.go.id/assets/files/ storage/2014/06/ file_storage_1404095485.pdf
Law of The Republic of Indonesia Number 12 of 2011 concerning The Legislations Making (Undang-undang Nomor 12 Tahun 2011 tentang Pembentukan Peraturan Perundang-undangan). Retrieved from https://bphn.go.id/ data/documents/11uuo12.pdf

Marzuki, P. M. (2016). Penelitian hukum (edisi revisi). Jakarta: Kencana Prenada Media Group.

Meijers, D. (2019). Foresight at the ECA. European Court of Auditors EUROSAI Innovations, 2-4. Retrieved from https://www.eurosai.org/handle404? exporturi=/export/sites/ eurosai/.content/documents/ ESP_2017_2023/SG1/Innovations-in -EUROSAI_No-4_2019-12.pdf

Minarno, N. B. (2010). Penyalahgunaan wewenang dalam pengelolaan keuangan daerah. Yogyakarta: Laksbang Mediatama.

Montero, A. G., \& LeBlanc, D. (2019). The role of external audits in enhancing transparency and accountability for sustainable development goals. DESA Working Paper, 157, 1-29. Retrieved from https://www.un.org/esa/desa/ papers/2019/wp157_2019.pdf

Muhammad, A. (2004). Hukum dan penelitian hukum. Bandung: PT Citra Aditya Bakti.

Nawiasky, H. (1948). Allgemeine als recht system lichen grundbegriffe (Cet 2.) Ensiedenln/Zurich/Koln, Benziger.

Niemenmaa, V. (2019). The joy and pain of training on sustainable development goals. European Court of Auditors Journal, 3, 40-43. Retrieved from https://www.eca.europa.eu/lists/ ecadocuments/journal19_03/ journal19_03.pdf

Niestroy, I. (2019). SDG watch Europe: Civil society organizations join forces to support SDGs. European Court of Auditors Journal, 3, 90-92. Retrieved from https://www.eca.europa.eu/ lists/ecadocuments/journal19_03/ journal19_03.pdf

Nusantara, A. H. G. (1988). Politik hukum Indonesia. Jakarta: YLBHI.

OECD. (2015). OECD public governance reviews: Supreme audit institutions and good governance - oversight, 
insight, and foresight. Paris: OECD Publishing.

OECD. (2017). OECD public governance reviews: Brazil's Federal Court of Accounts - insight and foresight for better governance. Paris: OECD Publishing.

OLACEFS. (2017). Capacity Building Plan 2016-2018. Brazil: OLACEFS. Retrieved from https://www.olacefs. com/wp-content/uploads/2017/o7/

Plano-de-Capacitac\%cc\%a7a\%cc\% 830-do-CCC_Ing_webFINAL.pdf

Owen, P. W. (2019). From auditing sustainable environment issues to auditing the 2030 agenda. European Court of Auditors Journal, 3, 31-35. Retrieved from https://www.eca.europa.eu/ lists/ecadocuments/journal19_03/ journal19_03.pdf

Pesce-Monteiro, B. (2019). The race for sustainable development: We can only win if we run together. European Court of Auditors Journal, 3, 93-96. Retrieved from https:// www.eca.europa.eu/lists/ ecadocuments/journal19_03/ journal19_03.pdf

Pramono, A. J. (2016). Analisis faktor-faktor yang memengaruhi transformasi kapabilitas organisasi dan peran Badan Pemeriksa Keuangan RI. Jurmal Tata Kelola dan Akuntabilitas Keuangan Negara, 2(2), 175-193. DOI: 10.28986/jtaken.v2i2.63

Pramono, A. J., \& Hendarto, H. (2017). Model Transformasi Badan Pemeriksa Keuangan Republik Indonesia. Jurnal Tata Kelola dan Akuntabilitas Keuangan Negara, 3(2), 91-111. DOI: $10.28986 /$ jtaken.v3i2.105

Presidential Regulation Number 59 of 2017 on the Implementation of the Achievement of Sustainable Development Goals (Peraturan Presiden Nomor 59 Tahun 2017 tentang Pelaksanaan Pencapaian Tujuan Pembangunan Berkelanjutan). Retrieved from https://peraturan.bpk.go.id/ Home/Details/72974/perpres-no-59tahun-2017

Pulgar, O. R. (2019). SDGs beyond Europe Latin American dan Caribbean SAIs cooperate on auditing the SDG on gender equality. European Court of
Auditors Journal, 3, 44-49. Retrieved from https://www.eca.europa.eu/ lists/ecadocuments/journal19_03/ journal19_03.pdf

Radjab, D. (2005). Hukum tata negara Indonesia. Jakarta: Rineka Cipta.

Rajaguguk, B. W., Yatnaputra, I. G. B. T., \& Paulus, A. (2017). Preparing supreme audit institutions for sustainable development goals. INTOSAI Journal of Government Auditing. Retrieved from http://intosaijournal.org/ preparing-supreme-audit-institutions -for-sustainable-development-goals/

Ranggawidjaja, R. (1998). Pengantar ilmu perundang-undangan. Bandung: Mandar Maju.

Ridwan, H. R. (2007). Hukum administrasi negara. Jakarta: Raja Grafindo Persada.

Sadiq, R., \& Mushtaq, A. (2015). The Role of Islamic Finance in Sustainable Development Goals, Jourmal of Islamic Thought and Civilization, 5(1).

Saidi, M. D. (2013). Hukum keuangan negara. Jakarta: Raja Grafindo Persada.

Simanjuntak, E. G. H. (2019). Tujuan pembangunan berkelanjutan (TPB)/ SDGs dan perspektif pembangunan berkelanjutan. Paper presented at Knowledge Transfer Forum, Kendari, Indonesia.

Soemantri, S. (1992). Bunga rampai hukum tata negara Indonesia. Bandung: Alumni.

Suseno, F. M. (1997). Mencari sosok demokrasi: Sebuah telaah filosofis. Jakarta: Gramedia.

Tamanaha, B. Z. (2004). On the rule of law, history, politics, theory. United Kingdom: Cambridge University Press.

The 1945 Constitution of the Republic of Indonesia (Undang-undang Dasar Negara Republik Indonesia Tahun 1945). Retrieved from https:// www.bappenas.go.id/files/ pendanaan/regulasi/uud-1945perubahan-iiiiiiiv.pdf

Tutik, T. T. (2010). Konstruksi hukum tata negara Indonesia pasca UUD 1945. Jakarta: Kencana.

United Nations. (2015a). The 17 goals. Re- 
trieved from https://sdgs.un.org/ goals

United Nations. (2015b). Transforming our world: The 2030 agenda for sustainable development. Retrieved from https://

sustainabledevelopment.un.org/ post2015/transformingourworld

United Nations Development Programme (UNDP). (2015). Localizing agenda 2030 and the SDGs: UNDG's "MAPS" approach in Cambodia. Retrieved from https://https:// www.unescap.org/sites/default/files/ UNDG_MAPS_o.pdf

United Nations Development Group (UNDG). (2017). Mainstreaming the 2030 agenda for sustainable development - reference guide to $U N$ country teams. New York: UNDG. Retrieved from https:// unsdg.un.org/download/319/503

Vries, G. d. (2019). Auditing SDG Financing: Towards a European Agenda. European Court of Auditors Journal, 3, 61 -64. Retrieved from https:// www.eca.europa.eu/lists/ ecadocuments/journal19_03/ journal19_03.pdf

Wignjosoebroto, S. (1974). Penelitian hukum: Sebuah tipologi. Majalah Masyarakat Indonesia, 1(2).

Wilig, J. T. (1995). Auditing for environmental quality leadership. New York: John Wiley \& Sons, Inc.

Zoethout, C. M., Tang, G. v. d., Akkermans, P. (1993). Control in constitutional law. Dordrecht: Martinus Nijhoff Publishers.

Selected and Revised Papers from The International Conference of State Finance and Accountabillity (InCSFA 2019) (Badan Pemeriksa Keuangan Republik Indonesia, by $10^{\text {th }}$ October 2019) after peer-reviewed by Organizing Committee of InCSFA and Peer-reviewers of Jurnal Tata Kelola dan Akuntabilitas Keuangan Negara 